\title{
PENGARUH STRATEGI PEMBELAJARAN DAN JENIS KELAMIN TERHADAP HASIL BELAJAR BAHASA INDONESIA
}

\author{
Rizka Eka Putera ${ }^{1}$ dan Abdul Muin Sibuea ${ }^{2}$ \\ SMA Negeri 1 Tanjungtiram Sumatera Utaral dan Universitas Negeri Medan ${ }^{2}$ \\ rizkaekaputra@yahoo.com ${ }^{1}$ dan muin_sibuea@yahoo.com ${ }^{2}$
}

\begin{abstract}
Abstrak: Penelitian ini bertujuan untuk mengetahui: (1) perbedaan hasil belajar bahasa Indonesia siswa yang diajar dengan menggunakan strategi pembelajaran masyarakat belajar dan strategi pembelajaran inkuiri, (2) perbedaan hasil belajar bahasa Indonesia siswa yang berjenis kelamin laki-laki dan perempuan, dan (3) interaksi antara strategi pembelajaran dan jenis kelamin terhadap hasil belajar bahasa Indonesia. Penelitian ini merupakan penelitian quasi eksperimen. Penelitian dilakukan di kelas XI SMA Negeri 1 Tanjungtiram. Teknik analisis data statistik deskriptif dan statistik inferensial untuk menguji hipotesis penelitian. Hipotesis penelitian diuji dengan ANAVA dua jalur yang sebelumnya dilakukan uji persyaratan analisis data yaitu uji normalitas dan uji homogenitas. Hasil penelitian menunjukkan bahwa: (1) hasil belajar bahasa Indonesia siswa yang diajar dengan menggunakan strategi pembelajaran masyarakat belajar lebih tinggi daripada yang dibelajarkan dengan strategi pembelajaran inkuiri, ditunjukkan oleh $F_{\text {hitung }}=$ $78>F_{\text {tabel }}=4,17$, (2) siswa yang berjenis kelamin perempuan memperoleh hasil belajar bahasa Indonesia yang lebih tinggi daripada siswa yang berjenis kelamin laki-laki, ditunjukkan oleh $F_{\text {hitung }}=7,47>F_{\text {tabel }}=4,17$, dan (3) terdapat interaksi antara strategi pembelajaran dan jenis kelamin dalam memengaruhi hasil belajar bahasa Indonesia, ditunjukkan oleh $F_{\text {hitung }}=87,29>$ $F_{\text {tabel }}=4,17$.
\end{abstract}

Kata kunci: strategi pembelajaran, jenis kelamin, hasil belajar bahasa indonesia

Abstract: This study aims to determine: (1) differences in learning outcomes of Indonesian students who are taught using learning strategies learning society and learning strategies of inquiry, (2) differences in learning outcomes Indonesian student-sex male and female, and (3) the interaction between learning strategy and gender on the results of learning Indonesian. This research is a quasi experimental. The study was conducted in class XI SMA Negeri 1 Tanjungtiram. Descriptive statistical data analysis techniques and inferential statistics to test hypotheses of the study. The research hypothesis was tested by ANOVA two previous track test data analysis requirements that normality test and homogeneity test. The results showed that: (1) the learning outcomes Indonesian students who are taught using learning strategies learning community is higher than that learned by inquiry learning strategy, demonstrated by $F c=78>F t=4.17$, (2) student sex women acquire Indonesian study results were higher than students who are male sex, shown by $>F t, \quad F c=7.47=$ 4.17, and (3) there is interaction between learning strategies and gender in affecting learning outcomes Indonesian, indicated by $F c=87.29>F t=4.17$.

Keywords: learning strategies, gender, learning outcomes Indonesian

\section{PENDAHULUAN}

Menurut Badudu (1980:13), Pendidikan bahasa Indonesia merupakan salah satu aspek penting yang perlu diajarkan kepada siswa di sekolah. Tak heran apabila pelajaran ini kemudian diberikan sejak masih duduk di bangku SD hingga lulus SMA. Dari pembelajaran tersebut diharapkan siswa mampu menguasai, memahami, dan dapat mengimplementasikan keterampilan berbahasa, yang mencakup menyimak (listening), berbicara (speaking), membaca (reading), dan menulis (writing), dalam kehidupan sehari-hari. Kemudian pada tingkat SMP dan SMA, siswa juga mulai dikenalkan pada dunia kesastraan yang menitikberatkan pada tata bahasa, ilmu bahasa, dan berbagai apresiasi sastra. Artinya, telah dua belas tahun siswa merasakan kegiatan belajar mengajar di bangku sekolah dan selama itu pula pelajaran bahasa Indonesia tidak pernah absen menemani mereka. Tetapi kenyataan yang terjadi adalah kualitas berbahasa 
Indonesia para siswa yang telah lulus SMA masih saja jauh dari apa yang dicita-citakan sebelumnya.

Menurut Chaer (2007), permasalahan lain yang muncul dalam pembelajaran bahasa Indonesia di sekolah antara lain: (1) pembelajaran belum sepenuhnya menekankan pada kemampuan berbahasa, tetapi lebih pada penguasaan materi, hal ini terlihat dari porsi materi yang tercantum dalam buku paket lebih banyak diberikan oleh guru dibandingkan pelatihan berbahasa yang sifatnya lisan ataupun praktik; (2) persepsi sebagian guru yang menganggap bahwa keberhasilan siswa lebih banyak dilihat dari nilai UN. Akibatnya, materi yang diberikan kepada siswa sekadar membuat mereka dapat menjawab soal-soal tersebut, tetapi tidak mempunyai kemampuan memahami dan mengimplementasikan materi tersebut untuk kepentingan praktis dan kemampuan berbahasa mereka. Ironisnya, kemampuan penguasaan bahasa Indonesia siswa SMA masih rendah. Kompetensi kebahasaan siswa masih kurang baik, karena yang terjadi adalah penurunan dan bukan peningkatan dari tahun sebelumnya. Berikut ini tabel rata-rata nilai UN bahasa Indonesia tiga tahun terakhir secara nasional.

Sejalan dengan tujuan utama pembelajaran bahasa Indonesia yaitu agar siswa memiliki kemahiran berbahasa diperlukan sebuah alternatif baru yang lebih variatif, aplikatif, dan menarik dalam pengajaran bahasa Indonesia di sekolah. Pembelajaran yang menarik akan memikat anak didik untuk terus dan betah mempelajari bahasa Indonesia sebagai bahasa ke-2 setelah bahasa ibu. Apabila siswa sudah tertarik dalam pembelajaran maka akan dengan mudah meningkatkan prestasi siswa dalam bidang bahasa (Kuntjara, 2004). Salah satu strategi pembelajaran yang variatif, aplikatif, dan menarik adalah masyarakat belajar (learning community) yang menekankan kepada kerja sama kelompok untuk menyelesaikan sebuah masalah. Dalam strategi ini, siswa ditempatkan dalam tim belajar beranggotakan $4-5$ orang yang heterogen menurut tingkat prestasi, jenis kelamin, dan suku. Guru menyajikan pelajaran, siswa bekerja dalam tim mereka untuk memastikan seluruh anggota tim telah menguasai pelajaran tersebut. Saat belajar kelompok, siswa saling membantu untuk menuntaskan materi yang dipelajari.Guru memantau dan mengelilingi tiap kelompok untuk melihat adanya kemungkinan siswa yang memerlukan bantuan guru.Strategi pemebelajaran ini juga dibantu oleh pelatihan, penugasan, ceramah, dan tanya jawab sesuai satuan pelajaran sehingga tujuan pembelajaran dapat terwujud.

Khusus mata pelajaran bahasa Indonesia, berdasarkan hasil analisis penelitian terhadap rendahnya hasil belajar peserta didik (Trianto, 2008:4; Ansari, 2007:4), bahwa strategi pembelajaran yang digunakan guru terlalu menekankan pada penguasaan jumlah informasi/konsep belaka. Penumpukan informasi/konsep pada subjek didik dapat saja kurang bermanfaat bahkan tidak bermanfaat sama sekali kalau hal tersebut hanya dikomunikasikan oleh guru kepada subjek didik melalui satu arah seperti menuang air ke dalam sebuah gelas. Tidak dapat disangkal, bahwa konsep merupakan suatu hal yang sangat penting, namun bukan terletak pada konsep itu sendiri, tetapi terletak pada bagaimana konsep itu dipahami oleh subjek didik. Pentingnya pemahaman konsep dalam proses belajar mengajar sangat mempengaruhi sikap, keputusan, dan cara-cara memecahkan masalah. Kenyataan yang terjadi adalah siswa hanya menghafal konsep dan kurang mampu menggunakan konsep tersebut jika menemui masalah dalam kehidupan nyata yang berhubungan dengan konsep yang dimiliki. Lebih jauh lagi bahkan siswa kurang mampu menentukan masalah dan merumuskannya.

Upaya yang dapat dilakukan oleh guru untuk memperbaiki dan meningkatkan kualitas pembelajaran adalah memilih strategi pembelajaran yang tepat yang sesuai dengan karakteristik siswa. Meminjam pendapat Slavin dan Hamachek (dalam Panjaitan, 2006:3), bahwa karakteristik siswa adalah aspek-aspek yang ada di dalam diri siswa yang dapar mempengaruhi perilakunya. Aspek-aspek itu bisa berupa bakat, motivasi berprestasi, gaya kognitif, persepsi, sikap, lokus kendali, kemampuan awal, strategi belajar, kemampuan berpikir logis, kemampuan berpikir kreatif, ketekunan belajar, kecerdasan, jenis kelamin, etnis, dan aspek-aspek lain pada diri pebelajar yang dapat mempengaruhi perilakunya. Salah satu karakteristik siswa yang tidak kalah pentingnya adalah perbedaan jenis kelamin.

Coates (1986) dalam Santoso (2009), berpendapat bahwa terdapat perbedaan bahasa antara laki-laki dan perempuan. Bahasa perempuan memiliki karakteristik khas yang membedakannya dengan bahasa laki-laki. Hal 
ini tidak mengejutkan ketika dalam masyarakat masih memisahkan dan membedakan peranperan sosial antara laki-laki dan perempuan tentang pendistribusian tindak permintaan maaf atau tindak apologi untuk menjelaskan apologi untuk menjelaskan kompleksitas tugas pembelajar bahasa dalam memperoleh kompetensi komunikatif. Artinya, perempuan lebih banyak menggunakan strategi kesantunan daripada laki-laki.

Hakikat hasil belajar merupakan tindakan dan perilaku siswa yang kompleks. Siswa merupakan bagian dari faktor penentu terjadinya proses pembelajaran yang efektif dan efisien. Aktivitas belajar siswa merupakan dorongan dari rasa keingintahuan dan merupakan kebutuhan saat itu. Reigeluth (1983:25) secara umum mengkategorikan indikator keberhasilan siswa dalam belajar terdiri dari tiga hal yaitu: (1) efektivitas pembelajaran (effectiveness), yang biasanya diukur dari tingkat keberhasilan siswa dalam berbagai hal, (2) efisiensi pembelajaran (efficiency), yang biasanya diukur dari waktu dan pembiayaan, dan (3) daya tarik pembelajaran (appeal), yang selalu diukur dari tendensi siswa untuk belajar secara terus menerus. Dengan mengacu pada uraian tersebut dapat disimpulkan bahwa keberhasilan suatu kegiatan pembelajaran dapat dilihat melalui tiga hal, yaitu efektivitas, efisiensi, dan daya tarik.

Romiszowski (1981:379) berpendapat bahwa hasil belajar diperoleh dalam pengetahuan dan keterampilan. Pengetahuan dikelompokkan ke dalam empat bagian, yaitu : fakta, konsep, prosedur, dan prinsip. Pengetahuan adalah semua informasi yang ditangkap oleh indera seseorang dan selanjutnya disimpan dalam otak. Keterampilan adalah suatu aksi tingkah laku yang mampu memperlihatkan seseorang itu terampil. Fakta merupakan pengetahuan objek nyata. Asosiasi dari kenyataan yang didapat melalui pengamatan ini diolah dan disajikan ilmuwan menjadi data. Konsep adalah suatu ide atau gagasan yang digeneralisasikan dari pengalaman-pengalaman tertentu dan relevan. Prinsip merupakan generalisasi yang meliputi konsep-konsep yang berkaitan dan bersifat kausalitas, korelasi, dan aksiomatis. Prosedur merupakan pengetahuan tentang tindakan.

Dick, Carey dan Carey Junior (2005) mengemukakan bahwa strategi pembelajaran merupakan komponen umum dari bahan pembelajaran dan prosedur yang akan digunakan untuk menghasilkan suatu hasil belajar pada siswa, yang berkenaan dengan pendekatan pembelajaran untuk menyampaikan materi secara sistematik sehingga kemampuan yang diharapkan dapat dikuasai secara efektif dan efisien. Lebih lanjut Dick, Carey dan Carey Junior (2005) menjelaskan bahwa ada 5 (lima) kompenen strategi pembelajaran : (1) prainstruksional, yang meliputi: memotivasi siswa, .deskripsi materi, dan analisis perilaku awal; (2) penyajian informasi, yang meliputi : penjelasan tujuan pembelajaran, uraian isi materi dan contoh; (3) partisipasi siswa, yang meliputi : latihan dan umpan balik; (4) penilaian (tes), yang meliputi : tes perilaku awal, pretes, dan postes; dan (5) tindak lanjut, yang meliputi : bantuan kesan untuk ingatan dan pertimbangan.

Sementara itu, Gerlach dan Ely (1980) mendefinisikan bahwa strategi pembelajaran merupakan semua metode mengajar yang dapat dipakai guru untuk menyampaikan materi, mulai dari ekspositori sampai ke metode discovery dan tugas guru adalah memilih strategi pembelajaran tersebut untuk menyampaikan materi. Sementara itu, Uno (2008:45) berpendapat bahwa strategi pembelajaran merupakan hal yang perlu diperhatikan guru dalam proses pembelajaran. Paling tidak ada tiga jenis strategi pembelajaran, yakni : (1) strategi pengorganisasian pembelajaran, (2) strategi penyampaian pembelajaran, dan (3) strategi pengelolaan pembelajaran.

Sebagai model pembelajaran yang sistematis yang mengelompokkan siswa untuk tujuan menciptakan pendekatan pembelajaran efektif, staretegi pembelajaran masyarakat belajar (learning community) mengintegrasikan keterampilan sosial yang bermuatan akademis. Karena itu, learning community didasarkan pada teori-teori perkembangan kognitif, perlakuan, dan persandaran sosial. Ide-ide dari konsep strategi pembelajaran masyarakat belajar (learning community) banyak berlandaskan pada teori pembelajaran sosial Vygotsky (Vygotsky Constructivisme Social). Teori Vygotsky berasaskan kepada premis bahwa pengetahuan terbina dari interaksi kumpulan dalam menyelesaikan masalah dan teori perlakuan yang diperbincangkan dalam teori ini melibatkan perspektif, sikap, motivasi, kemampuan berpikir kritis, memiliki keterampilan sosial, dan mampu menyelesaikan masalah, yaitu pemberian ganjaran dapat memberi ransangan kepada siswa untuk bekerja 
sama dalam kumpulan belajar. Vygotsky berkeyakinan bahwa perkembangan siswa tergantung pada faktor biologis, yang menentukan fungsi-fungsi elementer memori, atensi, persepsi, dan stimulus-respon, dan faktor sosial yang sangat penting artinya bagi perkembangan fungsi mental lebih tinggi untuk pengembangan konsep, penalaran logis, dan pengambilan keputusan.

Teori Vygotsky ini lebih menekankan pada aspek sosial dari pembelajaran. Vygotsky mengemukakan bahwa siswa belajar melalui interaksi dengan orang dewasa atau teman sebaya yang lebih mampu. Menurut Vygotsky, proses pembelajaran akan terjadi jika anak bekerja atau menangani tugas-tugas yang belum dipelajari, namun tugas-tugas tersebut masih berada dalam jangkauan mereka yang disebut dengan zone of proximal development, yakni daerah tingkat perkembangan sedikit di atas daerah perkembangan seseorang saat ini. Vygotsky yakin bahwa fungsi mental yang lebih tinggi pada umumnya muncul dalam percakapan dan kerja sama antar individu sebelum fungsi mental yang lebih tinggi itu diserap ke dalam individu tersebut. Ide penting lain yang diturunkan Vygotsky adalah scaffolding, yaitu memberikan sejumlah bantuan kepada siswa pada tahap-tahap awal pembelajaran, kemudian menguranginya dan memberi kesempatan kepada siswa untuk mengambil alih tanggung jawab saat mereka mampu. Bantuan tersebut berupa petunjuk, peringatan, dorongan, menguraikan masalah pada langkah-langkah pemecahan, memberi contoh atau hal-hal lain yang memungkinkan siswa tumbuh mandiri. Vygotsky juga menambahkan ada hubungan antara domain kognitif dengan sosial budaya. Kualitas berpikir siswa dibangun di dalam ruangan kelas, sedangkan aktivitas sosialnya dikembangkan dalam bentuk keja sama antar siswa dengan siswa lainnya yang lebih mampu di bawah bimbingan orang dewasa dalam hal ini guru (Vygotsky, dalam Sujiono, 2008)

Inkuiri berasal dari bahasa Inggris "inquiry" yang artinya pertanyaan, pemeriksaan, penyelidikan. Ide-ide dari konsep strategi pembelajaran inkuiri (inquiry learning) banyak berlandaskan pada teori pembelajaran penemuan Jerome Bruner. Bruner menganggap bahwa belajar penemuan sesuai dengan pencarian pengetahuan secara aktif oleh manusia, dan dengan sendirinya memberi hasil yang paling baik. Berusaha sendiri untuk mencari pemecahan masalah serta pengetahuan yang menyertainya, menghasilkan pengetahuan yang benar-benar bermakna. Bruner menyarankan agar siswa-siswa hendaknya belajar melalui partisipasi aktif dengan konsepkonsep dan prinsip-prinsip agar mereka dianjurkan untuk memperoleh pengalaman dan melakukan eksperimen-eksperimen yang mengizinkan mereka untuk menemukan prinsip-prinsip itu sendiri. Strategi pembelajaran inkuiri berarti suatu rangkaian kegiatan belajar yang melibatkan secara maksimal seluruh kemampuan siswa untuk mencari dan menyelidiki secara sistematis, kritis, logis, analitis, sehingga siswa dapat merumuskan sendiri penemuannya dengan penuh percaya diri (Bruner,1984)

Model pembelajaran inkuiri dirancang untuk mengajak siswa secara langsung ke dalam proses ilmiah melalui latihan-latihan yang meringkaskan proses ilmiah itu ke dalam waktu yang relatif singkat. Pembelajaran inkuiri memberikan kesempatan kepada siswa untuk bereksplorasi dengan baik. Tujuan umum dari model inkuiri adalah membantu siswa mengembangkan keterampulan intelektual dan keterampilan-keterampilan lainnya, seperti mengajukan peertanyaan dan menemukan jawaban yang berasal dari keinginan mereka (Munadhi, 2008)

Menurut Isjoni (2009), pembelajaran inkuiri mengacu kepada pembelajaran melalui pengalaman yang memiliki karakteristik sebagai berikut : (1) berbuat dalam

kasus tertentu. Di sini orang melakukan sesuatu lalu melihat efeknya. Efek ini dapat saja berfungsi sebagai ganjaran atau hanya sekadar memberikan informasi mengenai hubungan kausalitas; (2) mengerti kasus, sehingga jika sejumlah keadaan yang sama muncul lagi, orang dapat mengantisipasi efeknya. Hal ini berarti orang tersebut telah belajar konstruksi dari tindakannya, dan oleh karena itu telah belajar bagaimana berbuat untuk mencapai tujuannya dalam kasus tersebut; (3) penggeneralisasian, yaitu dari contoh kasus ke pemahaman mengenai kaidah umum yang berlaku terhadap kasus-kasus dimaksud. Ini mungkin pengkajian sejumlah contoh sebelum dapat melihat secara jelas adanya kaidah ini. Mengerti kaidah umum tidak perlu berarti mampu mengekspresikannya dalam suatu lambang tertentu.

Teori perbedaan (differential of theory) merupakan teori yang menyatakan bahwa 
perempuan dan laki-laki mengembangkan gayagaya berbicara (styles of talking) yang berbeda secara sistemik dalam tahap-tahap penting kehidupan mereka (Wareing, 1999:79). Teori perbedaan memberikan penjelasan bahwa perempuan menginginkan hubungan-hubungan kolaborasi, keintiman, kesamaan, pemahaman, dukungan, dan pendekatan. Sebaliknya, lakilaki menurut dugaan menempatkan sebuah harga dari status dan kemerdekaan sebagai sesuatu yang penting, dan kurang berkenaan dengan perselisihan dan ketidaksamaan yang terus terang dalam hubungan mereka. Adanya gaya yang berbeda itu dapat membawa ketidaksepahaman antara laki-laki dan perempuan. Perbedaan gaya antara laki-laki dan perempuan berkaitan dengan dua faktor, yaitu faktor biologis dan faktor sosiologis. Faktor biologis menunjukkan bahwa laki-laki berbeda keseimbangan hormonnya yang berarti mereka lebih agresif daripada perempuan, sedangkan dari faktor sosiologis menunjukkan bahwa anak perempuan dihargai sejak awal pertumbuhannya untuk perilaku yang sopan dan meletakkan kebutuhan lainnya sesudah kebutuhan untuk berperilaku sopan itu. Sebaliknya, anak laki-laki dihormati dari sifat aktif-agresif dan semangatnya.

Sementara itu, beberapa penjelasan dapat dikemukakan tentang apa saja yang memotivasi laki-laki dan perempuan untuk menerapkan cara-cara bertutur yang berbeda. Penelitian antropologis menunjukkan bahwa terdapat perbedaan bahasa laki-laki dan perempuan (Graddol \& Swann, 1989). Dalam beberapa hal, perbedaan jenis kelamin dalam menggunakan ragam-ragam bahasa sepadan dengan perbedaan-perbedaan kualitas suara. Graddol \& Swann (1989) selanjutnya mengatakan bahwa ada tiga (3) cara yang populer untuk memperjelas fenomena tersebut, yaitu : (1) penjelasan sosiobiologis, yaitu suara laki-laki lebih tinggi, lebih berbobot, lebih kuat, lebih bertenaga, dan memiliki nada yang berbeda dibandingkan suara perempuan; (2) penjelasan sosiopsikologis, yaitu memasukkan konsep gender yang merupakan atribut psikologis yang membentuk sebuah kontinum dari sangat maskulin sampai sangat feminim. seorang laki-laki mungkin memiliki sejumlah karakteristik feminim tertentu sama seperti perempuan yang mempunyai sifat maskulin, dan (3) penjelasan sosiopolitis, yaitu perbedaan kualitas suara laki-laki dan perempuan tidak sepenuhnya bersifat konvensional dan sewenang-wenang (arbitrary). Artinya, tidak ada alasan instrinsik mengapa bahasa perempuan terdengar kurang memiliki otoritas sehingga makhluk perempuan hanya cocok untuk peran domestik dan tidak cocok untuk peran-peran publik, seperti politisi atau pengacara.

Perbedaan antara strategi pembelajaran masyarakat belajar dengan strategi pembelajaran inkuiri dapat dilihat pada tabel 1 .

Tabel 1. Perbedaan Strategi Pembelajaran Masyarakat Belajar dengan Strategi Pembelajaran Inkuiri

\begin{tabular}{|c|c|c|}
\hline No & $\begin{array}{l}\text { Strategi Pembelajaran } \\
\text { Masyarakat Belajar }\end{array}$ & $\begin{array}{l}\text { Strategi Pembelajaran } \\
\text { Inkuiri }\end{array}$ \\
\hline 1 & $\begin{array}{l}\text { Siswa diberdayakan dalam kegiatan } \\
\text { pembelajaran kelompok yang terarah, terpadu, } \\
\text { efektif, efisien, ke arah mencari atau mengkaji } \\
\text { sesuatu melalui proses kerjasama dan saling } \\
\text { membantu (sharing) sehingga tercapai proses } \\
\text { dan hasil belajar yang produktif (survive) }\end{array}$ & $\begin{array}{l}\text { Siswa diberdayakan dalam menemukan } \\
\text { sendiri informasi, ilmu pengetahuan, } \\
\text { dan keterampilan dalam mengatasi } \\
\text { persoalan belajarnya sesuai dengan } \\
\text { karakteristik dan kesulitan yang } \\
\text { berbeda pada masing-masing siswa. }\end{array}$ \\
\hline 2 & $\begin{array}{l}\text { Siswa memiliki keterampilan berpikir } \\
\text { (thinking skill) dan keterampilan sosial (social } \\
\text { skill), seperti keterampilan mengemukakan } \\
\text { pendapat, menerima saran dan masukan dari } \\
\text { orang lain, bekerja sama, rasa setia kawan, dan } \\
\text { mengurangi timbulnya perilaku menyimpang } \\
\text { dalam kehidupan kelas }\end{array}$ & $\begin{array}{l}\text { Siswa membangkitkan keingintahuan, } \\
\text { memotivasi siswa untuk terus } \\
\text { menemukan jawaban-jawaban, } \\
\text { memcahkan masalah belajar tanpa } \\
\text { pertolongan orang lain, dan } \\
\text { menganalisis serta memanipulasi } \\
\text { informasi. }\end{array}$ \\
\hline 3 & $\begin{array}{l}\text { Kompetitif pembelajaran dikontrol oleh siswa } \\
\text { sebab siswa yang pintar akan membagi }\end{array}$ & $\begin{array}{l}\text { Kompetisi dalam pembelajaran cukup } \\
\text { ketat sebab anak yang pintar akan terus }\end{array}$ \\
\hline
\end{tabular}




\begin{tabular}{|l|l|l|}
\hline $\begin{array}{l}\text { pengetahuannya kepada teman yang tidak tahu } \\
\text { (sharing) sehingga kesimpulan akhir dari } \\
\text { permasalahan pembelajaran yang dihadapi } \\
\text { adalah kesimpulan kelompok serta } \\
\text { pembelajaran tidak akan berhenti jika } \\
\text { kelompok belum memahami kesimpulan akhir } \\
\text { tersebut }\end{array}$ & $\begin{array}{l}\text { terasah kepintarannya sedangkan anak } \\
\text { dalam mengatasi permasalahan } \\
\text { pembelajarannya }\end{array}$ \\
\hline
\end{tabular}

Berdasarkan pembatasan masalah yang telah diuraikan di atas, rumusan masalah dalam penelitian ini adalah: (1) Apakah hasil belajar bahasa Indonesia siswa yang diajar dengan menggunakan strategi pembelajaran masyarakat belajar (learning community) lebih unggul daripada hasil belajar bahasa Indonesia yang diajar menggunakan strategi pembelajaran inkuiri (inquiry)?; (2) Apakah hasil belajar bahasa Indonesia siswa laki-laki lebih unggul daripada siswa perempuan?; dan (3) Apakah terdapat interaksi antara strategi pembelajaran dan perbedaan jenis kelamin terhadap hasil belajar bahasa Indonesia siswa SMA Negeri 1 Tanjungtiram?

\section{METODE}

Penelitian ini dilaksanakan di SMA Negeri 1 Tanjungtiram Kecamatan Tanjungtiram Kabupaten Batubara. Populasi penelitian ini sebanyak 175 orang. Teknik penarikan sampel dalam penelitian ini adalah cluster random sampling. Untuk menentukan jenis perlakukan dilakukan secara undian, di mana satu kelas mendapat perlakuan strategi pembelajaran masyarakat belajar, yaitu kelas XI 2 , dan kelas yang satu lagi mendapat perlakuan strategi pembelajaran inkuiri, yaitu kelas XI 5.
Metode yang diterapkan dalam penelitian ini adalah Quasi Experiment (Eksperimen Semu) yang bertujuan untuk mengetahui pengaruh strategi pembelajaran dan perbedaan jenis kelamin terhadap hasil belajar bahasa Indonesia. Penggunaan metode ini terkait dengan subjek peneliti yang tidak dapat dikendalikan secara penuh, karena penelitian dilakukan di sekolah karena berbagai kondisi seperti pembagian kelas, jumlah kelas, dan jadwal pembelajaran sudah ditentukan pihak sekolah.

Penelitian ini menggunakan desain faktorial $2 \times 2$ dengan dua variabel bebas dan satu variabel terikat. Melalui desain ini akan dibandingkan pengaruh strategi pembelajaran masyarakat belajar (learning community) dan strategi pembelajaran inkuiri (inquiry) terhadap hasil belajar bahasa Indonesia ditinjau dari perbedaan jenis kelamin. Strategi pembelajaran masyarakat belajar dan inkuiri diperlakukan pada kelompok eksperimen berjenis kelamin perempuan dan laki-laki. Strategi pembelajaran masyarakat belajar dan inkuiri sebagai variabel bebas, jenis kelamin perempuan dan laki-laki sebagai variabel moderator, dan hasil belajar bahasa Indonesia sebagai variabel terikat. Untuk lebih jelasnya dapat dilihat pada table 2 berikut ini.

Tabel 2. Desain Penelitian Faktorial 2 x 2

\begin{tabular}{|c|c|c|}
\hline Strategi Pembelajaran & $\begin{array}{c}\text { Masyarakat Belajar } \\
\text { (A1) }\end{array}$ & $\begin{array}{c}\text { Inkuiri } \\
\text { (A2) }\end{array}$ \\
\hline Jenis Kelamin & A1B1 & A2B1 \\
\hline Perempuan (B1) & A1B2 & A2B2 \\
\hline Laki-laki (B2) &
\end{tabular}

Keterangan :

A1B1 : Hasil belajar bahasa Indonesia menggunakan strategi pembelajaran masyarakat belajar dari siswa berjenis kelamin perempuan

A1B2 : Hasil belajar bahasa Indonesia menggunakan strategi pembelajaran masyarakat belajar dari siswa yang berjenis kelamin laki-laki
A2B1 : Hasil belajar bahasa Indonesia menggunakan strategi pembelajaran inkuiri dari siswa yang berjenis kelamin perempuan

A2B2 : Hasil belajar bahasa Indonesia menggunakan strategi pembelajaran inkuiri dari siswa yang berjenis kelamin laki-laki 
Teknik analisis data yang digunakan yang digunakan dalam penelitian ini adalah analisis varian (ANAVA) dua jalur (two way) pada taraf signifikansi $5 \%$. Sebelum data penelitian dianalisis, terlebih dahulu dilakukan uji persyaratan yang meliputi uji normalitas dan uji homogenitas. Uji normalitas merupakan pengujian tentang sampel-sampel yang ditentukan berasal dari populasi yang berdistribusi normal. Dengan kata lain, gejala yang ada pada sampel dapat digambarkan sebagai gejala keseluruhan anggota populasi. Uji normalitas ini dapat dilakukan dengan uji liliefors. Sedangkan uji homogenitas dilakukan dengan asumsi bahwa gejala dalam penelitian yaitu skor hasil belajar yang diperoleh siswa sebagai sampel dimana penyebaran atau varian dalam populasi bersifat homogen. Uji homogenitas ini dapat dilakukan dengan uji barlett.

Setelah uji persyaratan dilakukan, baru diteruskan menganalisis data. Analisis varians yang digunakan adalah untuk menguji hipotesis penelitian pertama, kedua, dan ketiga. Jika hipotesis penelitian yang ketiga signifikan maka dilanjutkan dengan uji perbandingan ganda. Uji lanjut yang digunakan adalah uji Tuckey bila jumlah sampel dari masing-masing sel sama sama, tetapi bila jumlah sampel dari masingmasing sel dalam rancangan penelitian tidak sama maka dilanjutkan dengan uji Scheffee.

Adapun hipotesis statistik yang akan diuji adalah :

1. Hipotesis pertama Ho: $\mu \mathrm{X} 1=\mu \mathrm{X} 2$

Ha: $\mu \mathrm{X} 1>\mu \mathrm{X} 2$

2. Hipotesis kedua Ho: $\mu \mathrm{Y} 1=\mu \mathrm{Y} 2$

Ha: $\mu \mathrm{Y} 1>\mu \mathrm{Y} 2$

3. Hipotesis ketiga Ho : $X \times Y=0$

Ha: $X \times Y \neq 0$

\section{HASIL PENELITIAN \\ Hasil}

Berdasarkan data skor hasil belajar bahasa Indonesia, langkah berikutnya adalah menghitung total skor dan rata-rata skor tiap kelompok perlakuan menurut Tabel ANAVA, yang selanjutnya dapat digunakan sebagai dasar keputusan statistik untuk pengujian hipotesis seperti pada Tabel 3 berikut ini.

Tabel 3. Rangkuman Hasil Perhitungan Statistik Dasar untuk ANAVA 2 Jalur

\begin{tabular}{|c|c|c|c|c|c|c|}
\hline $\begin{array}{ll} & \mathrm{SP}\end{array}$ & \multicolumn{2}{|c|}{ Masyarakat Belajar } & \multicolumn{2}{|r|}{ Inkuiri } & \multicolumn{2}{|r|}{ Total } \\
\hline \multirow{5}{*}{ Perempuan } & $\mathrm{N}$ & $=19$ & $\mathrm{~N}$ & $=19$ & $\mathrm{~N}$ & $=38$ \\
\hline & $\bar{X}$ & $=28,87$ & $\bar{X}$ & $=22,71$ & $\bar{X}$ & $=25,79$ \\
\hline & $\Sigma \mathrm{X}$ & $=548$ & $\Sigma \mathrm{X}$ & $=430$ & $\Sigma \mathrm{X}$ & $=978$ \\
\hline & $\Sigma X^{2}$ & $=15918$ & $\Sigma X$ & $=9876$ & $\Sigma X^{2}$ & $=25794$ \\
\hline & $\mathrm{Sd}$ & $=2,67$ & $\mathrm{Sd}$ & $=2,89$ & $\mathrm{Sd}$ & $=7,76$ \\
\hline \multirow{5}{*}{ Laki-laki } & $\mathrm{N}$ & $=15$ & $\mathrm{~N}$ & $=15$ & $\mathrm{~N}$ & $=30$ \\
\hline & $\bar{X}$ & $=29,60$ & $\bar{X}$ & $=22,97$ & $\bar{X}$ & $=21,29$ \\
\hline & $\Sigma \mathrm{X}$ & $=313$ & $\Sigma \mathrm{X}$ & $=345$ & $\Sigma X$ & $=658$ \\
\hline & $\Sigma \mathrm{X}^{2}$ & $=5787$ & $\Sigma \mathrm{X}$ & $=8011$ & $\Sigma X^{2}$ & $=13798$ \\
\hline & $\mathrm{Sd}$ & $=2,25$ & $\mathrm{Sd}$ & $=2,45$ & $\mathrm{Sd}$ & $=2,35$ \\
\hline \multirow{5}{*}{ Total } & $\mathrm{N}$ & $=34$ & $\mathrm{~N}$ & $=34$ & $\mathrm{~N}$ & $=68$ \\
\hline & $\bar{X}$ & $=24,24$ & $\bar{X}$ & $=22,84$ & $\bar{X}$ & $=47,08$ \\
\hline & $\Sigma \mathrm{X}$ & $=861$ & $\Sigma \mathrm{X}$ & $=775$ & $\Sigma X$ & $=1636$ \\
\hline & $\Sigma \mathrm{X}^{2}$ & $=21705$ & $\Sigma \mathrm{X}$ & $=17887$ & $\Sigma X^{2}$ & $=39592$ \\
\hline & $\mathrm{Sd}$ & $=2,46$ & $\mathrm{Sd}$ & $=2,67$ & $\mathrm{Sd}$ & $=5,13$ \\
\hline
\end{tabular}

\section{Pengujian Hipotesis} di bawah ini.

Secara keseluruhan hasil ANAVA untuk pengujian hipotesis dapat dilihat pada Tabel 4

Tabel 4. Rangkuman Hasil ANAVA Secara Keseluruhan Terhadap Hasil Belajar Bahasa Indonesia

\begin{tabular}{|l|l|l|l|l|l|} 
Sumber Variasi & JK & dk & KT & Fhit & Ftab \\
\hline
\end{tabular}




\begin{tabular}{|l|c|l|l|l|l|}
\hline Jenis Kelamin & 32,55 & 1 & 32,55 & 7,47 & 4,17 \\
Strategi Pembelajaran & 340,08 & 1 & 340,08 & 78 & 4,17 \\
$\begin{array}{l}\text { Interaksi Antara Strategi Pembelajaran } \\
\text { dan Jenis Kelamin }\end{array}$ & 380,60 & 1 & 380,60 & 87,29 & 4,17 \\
Dalam Kelompok (kekeliruan) & 279,04 & 64 & 4,36 & & \\
\cline { 1 - 4 } Total & 1032,27 & 67 & & & \\
\hline
\end{tabular}

Ringkasan hasil uji Scheffe' dapat dilihat pada Tabel 5 berikut ini.

Tabel 5. Ringkasan Hasil Perhitungan Uji Scheffe'

\begin{tabular}{|c|c|c|}
\hline Skor Kelompok yang dibandingkan & $\mathrm{F}_{\text {hitung }}$ & $\mathrm{F}_{\text {tabel }}(\alpha=0,05)$ \\
\hline$\mu \mathrm{A} 1 \mathrm{~B} 1$ dengan $\mu \mathrm{A} 2 \mathrm{~B} 1$ & 13,43 & 2,75 \\
\hline$\mu \mathrm{A} 1 \mathrm{~B} 1$ dengan $\mu \mathrm{A} 1 \mathrm{~B} 2$ & 17,82 & 2,75 \\
\hline$\mu \mathrm{A} 1 \mathrm{~B} 1$ dengan $\mu \mathrm{A} 2 \mathrm{~B} 2$ & 11,34 & 2,75 \\
\hline$\mu \mathrm{A} 2 \mathrm{~B} 2$ dengan $\mu \mathrm{A} 2 \mathrm{~B} 1$ & 4,34 & 2,75 \\
\hline$\mu \mathrm{A} 2 \mathrm{~B} 2$ dengan $\mu \mathrm{A} 1 \mathrm{~B} 2$ & 9,24 & 2,75 \\
\hline$\mu \mathrm{A} 2 \mathrm{~B} 1$ dengan $\mu \mathrm{A} 1 \mathrm{~B} 2$ & 4,31 & 2,75 \\
\hline
\end{tabular}

Keterangan :

$\mu \mathrm{A} 1 \mathrm{~B} 1=$ skor hasil belajar bahasa Indonesia siswa yang diajarkan dengan strategi pembelajaran masyarakat belajar untuk siswa berjenis kelamin perempuan

$\mu \mathrm{A} 2 \mathrm{~B} 1=$ skor hasil belajar bahasa Indonesia siswa yang diajarkan dengan strategi pembelajaran inkuiri untuk siswa berjenis kelamin perempuan

$\mu \mathrm{A} 1 \mathrm{~B} 2=$ skor hasil belajar bahasa Indonesia siswa yang diajarkan dengan strategi pembelajaran masyarakat belajar untuk siswa berjenis kelamin laki-laki

$\mu \mathrm{A} 2 \mathrm{~B} 2$ = skor hasil belajar bahasa Indonesia siswa yang diajarkan dengan strategi pembelajaran inkuiri untuk siswa berjenis kelamin laki-laki

Selanjutnya, adanya interaksi antara variabel strategi pembelajaran dan jenis kelamin terhadap hasil belajar bahasa Indonesia siswa, maka perlu diberikan ganbaran grafik estimasi yang menunjukkan adanya interaksi tersebut.

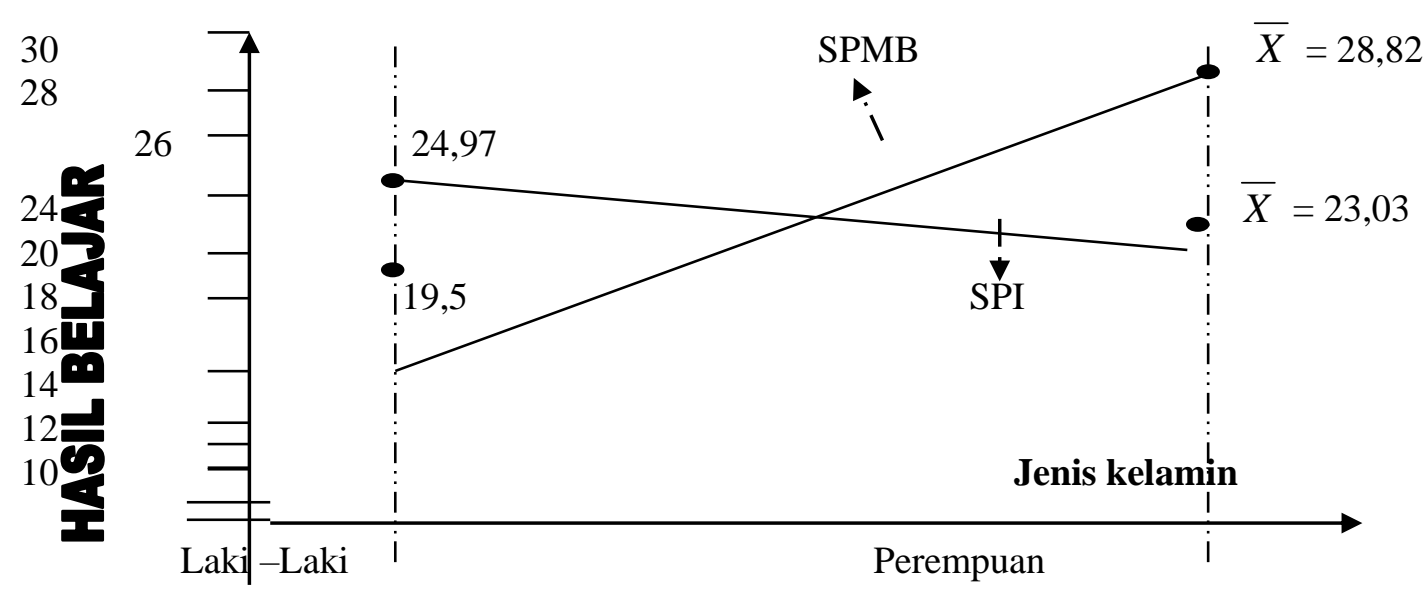

Gambar 1. Model Interaksi Antara Strategi Pembelajaran dan Jenis Kelamin Terhadap Hasil Belajar Bahasa Indonesia Siswa 


\section{Pembahasan}

Hasil penelitian ini telah menunjukkan bahwa hasil belajar bahasa Indonesia siswa yang dibelajarkan dengan strategi pembelajaran masyarakat belajar memperoleh skor rata-rata 24,97 dan skor rata-rata strategi pembelajaran inkuiri adalah 24,44 . Dari perbedaan skor ratarata dan hasil pengujian hipotesis terbukti bahwa hasil belajar bahasa Indonesia siswa yang dibelajarkan dengan strategi pembelajaran masyarakat belajar lebih tinggi dibandingkan dengan strategi pembelajaran inkuiri.

Dari uraian tersebut, dapat dipahami bahwa bahasa Indonesia memiliki cakupan yang luas, dengan demikian kegiatan pembelajaran harus memberikan kesempatan kepada siswa untuk menanggapi bahan pelajaran secara kritis dan analitis agar nilainilai yang terkandung dalam mata pelajaran bahasa Indonesia betul-betul dipahami dan diyakini oleh siswa, sehingga siswa dapat menerapkan dalam kehidupan sehari-hari. Untuk itu, guru diharapkan memiliki pengetahuan dan pemahaman mengenai strategi pembelajaran karena sangat penting sebagai salah satu upaya dalam memberikan pengalaman dan pencapaian tujuan belajar siswa secara optimal. Guru dituntut meningkatkan mutu pembelajaran dan harus memperhatikan hakikat, tujuan mata pelajaran, dan mempertimbangkan karakteristik siswa. Artinya, seorang guru harus dapat menentukan strategi mana yang paling tepat sehingga sesuai dengan tujuan dan materi yang akan disampaikan.

Pembelajaran bahasa Indonesia dengan strategi pembelajaran masyarakat belajar (learning community) menekankan pada proses pembelajaran yang didasari kerjasama (sharing) dengan orang lain yang bertujuan menanamkan sikap dan keterampilan serta memperoleh kemampuan memecahkan masalah melalui pembelajaran berkelompok. Kegiatan pembelajaran dalam strategi pembelajaran masyarakat belajar mencakup belajar bersama, berdiskusi, dan mencari solusi suatu permasalahan serta membuat konsep dari wacana yang mereka baca. Hal ini sejalan dengan pendapat Vygotsky (1930) bahwa perkembangan siswa tergantung pada faktor biologis, yang menentukan fungsi-fungsi elementer memori, atensi, persepsi, dan stimulus-respon, dan faktor sosial yang sangat penting artinya bagi perkembangan fungsi mental lebih tinggi untuk pengembangan konsep, penalaran logis, dan pengambilan keputusan. Teori Vygotsky ini lebih menekankan pada aspek sosial dari pembelajaran.

Vygotsky mengemukakan bahwa siswa belajar melalui interaksi dengan orang dewasa atau teman sebaya yang lebih mampu. Menurut Vygotsky, proses pembelajaran akan terjadi jika anak bekerja atau menangani tugas-tugas yang belum dipelajari, namun tugas-tugas tersebut masih berada dalam jangkauan mereka yang disebut dengan zone of proximal development, yakni daerah tingkat perkembangan sedikit di atas daerah perkembangan seseorang saat ini. Vygotsky yakin bahwa fungsi mental yang lebih tinggi pada umumnya muncul dalam percakapan dan kerja sama antar individu sebelum fungsi mental yang lebih tinggi itu diserap ke dalam individu tersebut. Ide penting lain yang diturunkan Vygotsky adalah scaffolding, yaitu memberikan sejumlah bantuan kepada siswa pada tahap-tahap awal pembelajaran, kemudian menguranginya dan memberi kesempatan kepada siswa untuk mengambil alih tanggung jawab saat mereka mampu. Bantuan tersebut berupa petunjuk, peringatan, dorongan, menguraikan masalah pada langkah-langkah pemecahan, memberi contoh atau hal-hal lain yang memungkinkan siswa tumbuh mandiri. Vygotsky juga menambahkan ada hubungan antara domain kognitif dengan sosial budaya. Kualitas berpikir siswa dibangun di dalam ruangan kelas, sedangkan aktivitas sosialnya dikembangkan dalam bentuk keja sama antar siswa dengan siswa lainnya yang lebih mampu di bawah bimbingan orang dewasa dalam hal ini guru

Sementara itu, pembelajaran bahasa Indonesia dengan strategi pembelajaran inkuiri (inquiry learning) banyak berlandaskan pada teori pembelajaran penemuan Jerome Bruner. Bruner menganggap bahwa belajar penemuan sesuai dengan pencarian pengetahuan secara aktif oleh manusia, dan dengan sendirinya memberi hasil yang paling baik. Berusaha sendiri untuk mencari pemecahan masalah serta pengetahuan yang menyertainya, menghasilkan pengetahuan yang benar-benar bermakna. Bruner menyarankan agar siswa-siswa hendaknya belajar melalui partisipasi aktif dengan konsep-konsep dan prinsip-prinsip agar mereka dianjurkan untuk memperoleh pengalaman dan melakukan eksperimeneksperimen yang mengizinkan mereka untuk menemukan prinsip-prinsip itu sendiri. Strategi 
pembelajaran inkuiri berarti suatu rangkaian kegiatan belajar yang melibatkan secara maksimal seluruh kemampuan siswa untuk mencari dan menyelidiki secara sistematis, kritis, logis, analitis, sehingga siswa dapat merumuskan sendiri penemuannya dengan penuh percaya diri (Bruner,1984)

Strategi pembelajaran inkuiri dirancang untuk mengajak siswa secara langsung ke dalam proses ilmiah melalui latihan-latihan yang meringkaskan proses ilmiah itu ke dalam waktu yang relatif singkat. Pembelajaran inkuiri memberikan kesempatan kepada siswa untuk bereksplorasi dengan baik. Tujuan umum dari model inkuiri adalah membantu siswa mengembangkan keterampulan intelektual dan keterampilan-keterampilan lainnya, seperti mengajukan pertanyaan dan menemukan jawaban yang berasal dari keinginan mereka. Sejalan dengan pendapat ini, Gulo (2002) mengemukakan bahwa pembelajaran inkuiri mengacu kepada pembelajaran melalui pengalaman yang memiliki karakteristik sebagai berikut: (1) berbuat dalam kasus tertentu. Di sini orang melakukan sesuatu lalu melihat efeknya. Efek ini dapat saja berfungsi sebagai ganjaran atau hanya sekadar memberikan informasi mengenai hubungan kausalitas; (2) mengerti kasus, sehingga jika sejumlah keadaan yang sama muncul lagi, orang dapat mengantisipasi efeknya. Hal ini berarti orang tersebut telah belajar konstruksi dari tindakannya, dan oleh karena itu telah belajar bagaimana berbuat untuk mencapai tujuannya dalam kasus tersebut; (3) penggeneralisasian, yaitu dari contoh kasus ke pemahaman mengenai kaidah umum yang berlaku terhadap kasus-kasus dimaksud. Ini mungkin pengkajian sejumlah contoh sebelum dapat melihat secara jelas adanya kaidah ini. Mengerti kaidah umum tidak perlu berarti mampu mengekspresikannya dalam suatu lambang tertentu.

Berdasarkan uraian di atas, dapat dipahami bahwa hasil belajar bahasa Indonesia siswa yang diajar dengan strategi pembelajaran masyarakat belajar lebih tinggi daripada strategi pembelajaran inkuiri. Namun, strategi pembelajaran masyarakat belajar juga memiliki beberapa kelemahan yang terjadi dalam proses pembelajarannya. Sebagai sebuah sistem pembelajaran, ada beberapa komponen yang perlu diperhatikan dalam proses pembelajaran, di antaranya guru, siswa, fasilitas, dan sebagainya. Kemampuan guru menyajikan materi pelajaran dengan menggunakan strategi pembelajaran masyarakat belajar dan inkuiri belum sepenuhnya teruji sehingga esensi mata pelajaran belum sepenuhnya tercapai. Di samping itu, guru belum juga terbiasa menyajikan materi dengan menggunakan strategi pembelajaran masyarakat belajar dan inkuiri.

Dalam perspektif Linguistik Fungsional Sistemik (LFS), bahasa merupakan semiotik sosial dan pemakain bahasa atau teks terstruktur berdasarkan kebutuhan manusia dalam mennggunakan bahasa. Dengan kata lain, struktur bahasa ditentukan oleh fungsi apa yang dilakukan bahasa (atau lebih tepat fungsi yang dilakukan manusia dengan menggunakan bahasa) untuk memenuhi kebutuhannya sebagai anggota masyarakat. Dalam setiap interaksi bahasa, pemakai bahasa menggunakan bahasa untuk memaparkan, mempertukarkan, dan merangkai atau mengorganisasikan pengalaman. Dengan kata lain, bahasa sekaligus berfungsi tiga hal dalam komunikasi, yakni memaparkan, mempertukarkan, dan merangkai pengalaman (Halliday, 1994) yang masingmasing fungsi itu dikatakan merealisasikan makna pengalaman (ideational meaning), makna pertukaran atau makna antarpersona (interpersonal meaning) dan makna perangkaian (textual meaning).

Dalam perspektif LFS, bahasa adalah semiotik. Berbeda dengan semiotik umum, semiotik bahasa adalah semiotik sosial, dengan pengertian bahasa adalah fenomena sosial dan berkonstruksi dengan konteks sosial. Sebagai semiotik sosial, bahasa terdiri atas 3 unsur, yaitu arti, bentuk, dan ekspresi, yang masingmasing secara teknis dikenal sebagai semantis, tata bahasa, dan fonologi (lisan), grafologi (tulisan) atau isyarat. Di luar bahasa terdapat konteks sosial, yang membentuk semiotik konotatif terhadap bahasa. Bahasa yang terdiri atas tiga unsur juga membentuk semiotik denotatif. Dengan demikian, semiotik bahasa terdiri atas semiotik denotatif dan semiotik konotatif. Sebagai semiotik konotatif, konteks sosial terdiri atas konteks situasi, budaya, dan ideologi. Konteks situasi (register) terjadi dari tiga komponen, yaitu medan (apa yang dibicarakan), pelibat ( siapa yang terlibat dalam interaksi), dan cara (bagaimana interaksi dilakukan. Konteks budaya (genre) merupakan nilai atau aturan yang menetapkan medan apa yang boleh atau potensial menyangkut pelibat dengan cara tertentu. Ideologi merupakan 
konstruksi sosial yang menjadi panduan/tujuan atau saringan dalam melakukan apa yang harus atau tidak dilakukan. Semiotik denotatif memiliki "arti" dan "ekspresi", yaitu arti atau semantik direalisasikan oleh bentuk atau tatabahasa. Selanjutnya, bentuk yang telah menjadi realisasi "arti" dan berfungsi sebagai "arti" direalisasikan oleh ekspresi. Ekspresi ini dapat berupa bunyi (fonologi) dalam bahasa lisan atau berupa huruf atau tulisan (grafologi), dalam bahasa tulisan atau isyarat.

Semiotik bahasa dan konteks sosial membentuk semiotik pemakaian bahasa. Artinya, semiotik pemakaian bahasa atau semiotik konteks sosial dan teks adalah gabungan semiotik denotatif dan semiotik konotatif. Beberapa pakar sosiolinguistik membahas kaitan bahasa dengan gender. Mereka mengemukakan perbedaan yang ada dalam cara laki-laki dan perempuan berkomunikasi. Tema yang banyak dibicarakan adalah tema dominance model. Model ini mengatakan bahwa bahasa yang digunakan laki-laki menunjukkan dominasi laki-laki, sedangkan bahasa perempuan merefleksikan subordinasi mereka. Model ini ditunjukkan misalnya dalam hal interupsi ketika orang berbicara. Biasanya laki-laki lebih dominan menginterupsi dibandingkan perempuan. Menurut Tannen (1990), cara berbahasa lakilaki dan perempuan memang berbeda, oleh sebab itu kita perlu saling memahami perbedaan yang ada dan bertoleransi.

Sementara itu, beberapa penjelasan dapat dikemukakan tentang apa saja yang memotivasi laki-laki dan perempuan untuk menerapkan cara-cara bertutur yang berbeda. Dalam beberapa hal, perbedaan jenis kelamin dalam menggunakan ragam-ragam bahasa sepadan dengan perbedaan-perbedaan kualitas suara. Menurut Graddol \& Swann (1989), ada tiga (3) cara yang populer untuk memperjelas fenomena tersebut, yaitu : (1) penjelasan sosiobiologis, yaitu suara laki-laki lebih tinggi, lebih berbobot, lebih kuat, lebih bertenaga, dan memiliki nada yang berbeda dibandingkan suara perempuan; (2) penjelasan sosiopsikologis, yaitu memasukkan konsep gender yang merupakan atribut psikologis yang membentuk sebuah kontinum dari sangat maskulin sampai sangat feminim. seorang lakilaki mungkin memiliki sejumlah karakteristik feminim tertentu sama seperti perempuan yang mempunyai sifat maskulin, dan (3) penjelasan sosiopolitis, yaitu perbedaan kualitas suara laki- laki dan perempuan tidak sepenuhnya bersifat konvensional dan sewenang-wenang (arbitrary). Artinya, tidak ada alasan instrinsik mengapa suara perempuan terdengar kurang memiliki otoritas sehingga makhluk perempuan hanya cocok untuk peran domestik dan tidak cocok untuk peran-peran publik, seperti politisi atau pengacara.

Pendidikan bahasa Indonesia merupakan salah satu aspek penting yang perlu diajarkan kepada siswa di sekolah. Tak heran apabila pelajaran ini kemudian diberikan sejak masih duduk di bangku SD hingga lulus SMA. Dari pembelajaran tersebut diharapkan siswa mampu menguasai, memahami, dan dapat mengimplementasikan keterampilan berbahasa, yang mencakup menyimak (listening), berbicara (speaking), membaca (reading), dan menulis (writing), dalam kehidupan sehari-hari. Dalam keseluruhan proses pendidikan di sekolah, kegiatan pembelajaran merupakan kegiatan yang paling esensial. Artinya, berhasil tidaknya pencapaian tujuan pendidikan tergantung pada proses yang dialami siswa sebagai peserta didik. Peningkatan mutu pendidikan tidak dapat tercapai sebelum peningkatan mutu pembelajaran. Dalam pelaksanaan pembelajaran, ada beberapa komponen yang dapat menentukan keberhasilan proses pendidikan yang dilaksanakan. Komponen tersebut adalah guru, kurikulum, siswa, materi pembelajaran, dan strategi pembelajaran termasuk di dalamnya metode dan media yang digunakan.

Salah satu masalah pokok dalam pembelajaran pada pendidikan formal (sekolah) dewasa ini adalah masih rendahnya daya serap peserta didik. Khusus mata pelajaran bahasa Indonesia parameternya adalah rerata hasil belajar peserta didik yang senantiasa masih sangat memprihatinkan. Prestasi ini tentunya merupakan hasil kondisi pembelajaran yang masih bersifat konvensional dan tidak menyentuh ranah dimensi peserta didik itu sendiri, yaitu bagaimana sebenarnya belajar itu (belajar untuk belajar). Dalam arti yang lebih substansial, bahwa proses pembelajaran hingga dewasa ini masih memberikan dominasi guru dan tidak memberikan akses bagi anak didik untuk berkembang secara mandiri melalui proses berpikirnya. Pada pembelajaran ini, suasana kelas cenderung teacher-centered sehingga siswa menjadi pasif. Meskipun demikian, guru lebih suka menerapkan model tersebut karena tidak memerlukan alat dan 
bahan praktik, cukup menjelaskan konsepkonsep yang ada pada buku ajar atau referensi lain. Dalam hal ini, siswa tidak diajarkan strategi belajar yang dapat memahami bagaimana belajar, berpikir, dan memotivasi diri sendiri. Masalah ini banyak dijumpai dalam proses belajar mengajar di kelas.

Sejalan dengan tujuan utama pembelajaran bahasa Indonesia yaitu agar siswa memiliki kemahiran berbahasa diperlukan sebuah alternatif baru yang lebih variatif, aplikatif, dan menarik dalam pengajaran bahasa Indonesia di sekolah. Pembelajaran yang menarik akan memikat anak didik untuk terus dan betah mempelajari bahasa Indonesia sebagai bahasa ke-2 setelah bahasa ibu. Apabila siswa sudah tertarik dalam pembelajaran maka akan dengan mudah meningkatkan prestasi siswa dalam bidang bahasa. Salah satu strategi pembelajaran yang variatif, aplikatif, dan menarik adalah masyarakat belajar (learning community) yang menekankan kepada kerja sama kelompok untuk menyelesaikan sebuah masalah. Dalam strategi ini, siswa ditempatkan dalam tim belajar beranggotakan $4-5$ orang yang heterogen menurut tingkat prestasi, jenis kelamin, dan suku. Guru menyajikan pelajaran, siswa bekerja dalam tim mereka untuk memastikan seluruh anggota tim telah menguasai pelajaran tersebut. Saat belajar kelompok, siswa saling membantu untuk menuntaskan materi yang dipelajari.Guru memantau dan mengelilingi tiap kelompok untuk melihat adanya kemungkinan siswa yang memerlukan bantuan guru.Strategi pemebelajaran ini juga dibantu oleh pelatihan, penugasan, ceramah, dan tanya jawab sesuai satuan pelajaran sehingga tujuan pembelajaran dapat terwujud.

Strategi pembelajaran masyarakat belajar (learning community) memiliki prinsip-prinsip belajar: (1) berfokus pada tugas-tugas; (2) bekerja secara kooperatif; (3) mencapai keputusan tim untuk setiap masalah; (4) yakin bahwa setiap anggota kelompok mengerti penyelesaian sebelum membubarkan diri; (5) mendengarkan secara hati-hati pada anggota dan mencoba membangun ide-ide mereka; (6) berbagi kepemimpinan dengan tim; (7) yakinkan bahwa setiap anggota berpartisipasi dan tidak seorang pun mendominasi pekerjaan; dan (8) bergantian mencatat hasil kerja tim.

Dari uraian tersebut, dapaat dipahami bahwa strategi pembelajaran masyarakat belajar (learning community) memiliki keunggulan, antara lain : (1) siswa bekerja sama dalam mencapai tujuan dengan menjunjung tinggi norma-norma kelompok; (2) siswa aktif membentuk dan mendorong semangat untuk sama-sama berhasil. Aktif berperan sebagai tutor dalam kelompok sehingga dapat meningkatkan keberhasilan kelompok; (3) interaksi antarsiswa membantu meningkatkan kemampuan siswa dalam berpendapat; dan (4) interaksi antarsiswa membantu meningkatkan perkembangan kognitif siswa.

Perbedaan jenis kelamin antara laki-laki dan perempuan berkaitan erat dengan keterampilan berbahasa yang meliputi kegiatan berbicara (speaking), mendengar (listening), membaca (reading), dan menulis (writing). Perempuan lebih memiliki motivasi dan kecerdasan linguistik yang lebih tinggi dibandingkan laki-laki, hal ini membuat perempuan lebih mudah mempelajari bahasa. Selain itu, motivasi belajar bahasa perempuan lebih tinggi jika dibandingkan dengan laki-laki, sehingga siswa perempuan lebih serius dalam belajar, sebaliknya siswa laki-laki kurang tertarik untuk belajar bahasa karena kegiatan berbahasa yang meliputi berbicara, mendengar, membaca, dan menulis dianggap sebagai sebuah kegiatan yang membosankan.

Strategi pembelajaran masyarakat belajar (learning community) lebih sesuai diterapkan kepada siswa perempuan karena minat belajar dan keingintahuan yang lebih besar dibandingkan dengan siswa laki-laki. Dalam masyarakat belajar, siswa perempuan lebih aktif dan mudah bekerja sama dengan teman dalam kelompoknya dibandingkan laki-laki sehingga memungkinkan mereka menemukan informasi yang terdapat dalam materi pembelajaran dan berpartisipasi aktif dalam kelompok. Penerapan strategi pembelajaran masyarakat belajar (learning community) pada siswa perempuan akan lebih memacu siswa untuk menambah kompetensi dalam bidang bahasa Indonesia karena mereka akan lebih termotivasi untuk menggali informasi pembelajaran yang disajikan dalam bentuk masyarakat belajar yang lebih mengutamakan kolaborasi dan saling membutuhkan antara satu dengan yang lainnya dan wadah dalam mengaktualisasikan diri untuk mengembangkan kemampuan berbahasa, baik lisan maupun tulisan.

Sebaliknya, strategi pembelajaran masyarakat belajar (learning community) kurang sesuai bila diberikan kepada siswa lakilaki. Salah satu faktornya adalah kurangnya 
minat laki-laki dalam pembelajaran bahasa terutama bahasa Indonesia sehingga tujuan pembelajaran kurang tercapai. Belajar dalam masyarakat belajar akan menjadi hal yang membosankan bagi siswa laki-laki karena umumnya siswa laki-laki lebih pasif dibandingkan siswa perempuan. Siswa laki-laki cenderung melakukan hal-hal yang lain di luar konteks pembelajaran dalam masyarakat belajar sehingga mereka akan menyuruh temantemannya dalam kelompok, terutama teman perempuan, untuk mengerjakan tugas dalam kelompok belajarnya.

Selanjutnya, siswa laki-laki jika menggunakan strategi pembelejaran inkuiri (inquiry) akan berusaha menemukan dan menggali informasi yang tekandung dalam materi pelajaran bahasa Indonesia. Strategi pembelajaran inkuiri menuntut siswa harus berpikir sendiri, mencari jawaban atas soal-soal yang dihadapinya. Hasil belajar penemuan mempunyai efek yang transfernya lebih baik pada hasil belajarnya, dan yang tidak kalah pentingnya secara menyeluruh belajar penemuan meningkatkan penalaran siswa dan kemampuan untuk berpikir bebas, secara khusus belajar penemuan melatih keterampilanketerampilan kognitif siswa untuk menemukan dan memecahkan masalah tanpa bantuan orang lain. Strategi pembelajaran inkuiri dirancang untuk mengajak siswa secara langsung ke dalam proses ilmiah melalui latihan-latihan yang meringkaskan proses ilmiah itu ke dalam waktu yang relatif singkat.

Dari uraian di atas dapat dipahami bahwa siswa perempuan akan memperoleh hasil belajar bahasa Indonesia lebih tinggi jika dibelajarkan dengan strategi pembelajaran masyarakat belajar (learning community), dibandingkan jika dibelajarkan dengan strategi pembelajaran inkuiri. Sebaliknya untuk siswa laki-laki akan memperoleh hasil belajar bahasa Indonesia lebih tinggi jika dibelajarkan dengan strategi pembelajaran inkuiri (inquiry), dibandingkan jika dibelajarkan dengan strategi pembelajaran masyarakat belajar.

\section{PENUTUP}

\section{Simpulan}

Hasil belajar bahasa Indonesia siswa SMA Negeri 1 Tanjungtiram yang diajar dengan strategi pembelajaran masyarakat belajar lebih tinggi dibandingkan dengan jika diajar dengan strategi pembelajaran inkuiri. Siswa yang berjenis kelamin perempuan memperoleh hasil belajar bahasa Indonesia yang lebih tinggi dibandingkan dengan siswa berjenis kelamin laki-laki.

Terdapat interaksi antara strategi pembelajaran dan jenis kelamin dalam mempengaruhi hasil belajar bahasa Indonesia siswa SMA Negeri 1 Tanjungtiram. Siswa yang berjenis kelamin perempuan lebih efektif dalam meningkatkan hasil belajar bahasa Indonesia menggunakan strategi pembelajaran masyarakat belajar. Sedangkan siswa berjenis kelamin lakilaki, ternyata strategi pembelajaran inkuiri lebih efektif dalam meningkatkan hasil belajar bahasa Indonesia dibandingkan jika menggunakan strategi pembelajaran masyarakat belajar.

\section{Saran}

Mengupayakan mutu pendidikan di SMA Negeri 1 Tanjungtiram dapat dikembangkan melalui proses pembelajaran yang bervariasi. Salah satu alternatif pengembangannya adalah melalui pemilihan strategi pembelajaran yang tepat dengan tujuan pembelajaran, materi pembelajaran, kemampuan, kondisi, dan karakteristik siswa. strategi yang dapat dipilih antara lain adalah strategi pembelajaran masyarakat belajar dan inkuiri. Untuk siswa yang berjenis kelamin perempuan penggunaan strategi pembelajaran masyarakat belajar sangat efektif dalam memberikan hasil belajar yang diharapkan, tetapi untuk siswa yang berjenis kelamin lakilaki penggunaan strategi pembelajaran inkuiri akan lebih efektif dalam memberikan hasil belajar bahasa Indonesia.

Diharapkan kepada guru bahasa Indonesia atau tenaga pengajar umumnya agar senantiasa memperhatikan dan mempertimbangkan faktor jenis kelamin sebagai pijakan dalam merancang pembelajaran. Selain itu, guru perlu melakukan pengkajian yang mendalam tentang karakteristik siswa untuk dijadikan pijakan atau acuan untuk mengoptimalkan penerapan strategi pembelajaran masyarakat belajar dalam pelajaran bahasa Indonesia secara efektif dan efisien.

Penelitian ini perlu ditindaklanjuti untuk setiap jenjang pendidikan dan pada sampel yang lebih luas serta variabel penelitian berbeda lainnya, dengan mempertimbangkan keterbatasan-keterbatasan dalam penelitian ini. 


\section{DAFTAR PUSTAKA}

Ansari, Khairil. 2007. Kompetensi Kebahasaan Guru Bahasa dan Sastra Indonesia. Makalah. Disajikan Pada Seminar Nasional. Medan : Unimed

Badudu, Jus.1980. Problematika Bahasa Indonesia. Jakarta : Gramedia

Bahri, Zainul. 2007. "Pengaruh Strategi Pembelajaran dan Tingkat Pengetahuan Peta Terhadap Hasil Belajar Geografi Siswa SMP Swasta PAB 3 Percut Sei Tuan." Tesis. Program Pascasarjana : Unimed

Chaer, Abdul. 2007. Linguistik Umum. Jakarta : Rineka Cipta

Crain, William. 1989. Theories of Development Concepts and Applications. Third Edition. New Jersey : Prentice Hall Englewood Clifs

Dahar,Ratna Wilis.1989. Teori-teori Belajar. Jakarta : Erlangga

Dalimunthe, Riana Magabe. 2010. "Pengaruh Strategi Pembelajaran dan Jenis Kelamin Terhadap Hasil Belajar IPA Siswa Kelas IX SMP Candra Kirana Medan Tahun Pembelajaran 2009 2010”. Tesis. Program Pascasarjana Universitas Negeri Medan

Depdiknas.2003. Kurikulum Berbasis Kompetensi. Jakarta

Dick, Walter, Carey, Lou, dan Carey Junior. 2005. The Systematic Design of Instruction. Fouth Edition. New York.: Harper Collin College Publisher

Dryden, Gordon dan Jeannette Vos. 1999. The Learning Revolution: To Change the Way the World Learns. New Zealand: The LearningWeb

Escarpit, Robert. 1958. Sociologie De La Litterature. Presses Universitaires de France

Hamalik, O. 2001. Pendekatan Baru Strategi Belajar Mengajar Berdasarkan CBSA. Bandung : Sinar Baru Algesindo

Hamidah dan Adi. 2003. "Performansi Bahasa Laki-laki dan Perempuan Pada Penggunaan Bahasa Indonesia dalam Komunikasi Formal". Tesis. Program Pascasarjana : Universitas Negeri Malang
Isjoni. 2008. Pembelajaran Kooperatif. Jakarta : Gramedia

Kuntjara, Ester. 2004. Gender dan Kekuasaan. Jakartta : Gunung Mulia

Munadhi, Yudhi. 2008. Media Pembelajaan. Jakarta : Gaung Persada Press

Nurgiyantoro, Burhan. 1988. Penilaian dalam Pengajaran Bahasa dan Sastra. Yogyakarta : BPFE

Panjaitan, Binsar. 2006. Karakteristik Pebelajar dan Kontribusinya Terhadap Hasil Belajar. Medan : Poda

Reigeluth,C.M.1983. Instructional Design Theories and Models: An Overview of Their Current Status. Hillsdale, NJ : Lawrence Erlbaum Associates

Romiszowski, A.J.1981. Designeing Instructional System. New York : Nicholas

Rudianto. 2008. "Pengaruh Strategi Pembelajaran dan Kemampuan Berpikir Verbal Terhadap Hasil Belajar Bahasa Indonesia Siswa SMP Negeri 1 Stabat Tahun Ajaran 2006/2007”. Tesis. Program Pascasarjana : Universitas Negeri Medan

Santoso, Anang. 2009. Bahasa Perempuan. Jakarta : Bumi Aksara

Sinaga, Rahman. 2006. "Pengaruh Model Pembelajaran dan Sikap Bahasa Terhadap Hasil Belajar Bahasa Indonesia Siswa Kelas I SMP Negeri I Silima Pumggapungga Kabupaten Dairi”. Tesis. Program Pascasarjana : Universitas Negeri Medan

Soekamto, Toeti. 1993. Perancangan dan Pengembangan Sistem Instruksional. Program Pascasarjana : IKIP Jakarta

Susie. 2010. “Pengaruh Strategi Pembelajaran dan Jenis Kelamin Terhadap Hasil Belajar Bahasa Mandarin Siswa Kelas XI SMA Budi Luhur Lubuk Pakam Tahun Pembelajaran 20009 - 2010.” Tesis. Program Pascasarjana : Universitas Negeri Medan

Trianto. 2008. Mendesain Pembelajaran Kontekstual di Kelas. Jakarta : Cerdas Pustaka

Uno, Hamzah B. 2008. Perencanaan Pembelajaran. Jakarta : Bumi Aksara 